\title{
DIGITAL TRANSFORMATION AS AN EFFORT TO INCREASE FINANCIAL PERFORMANCE
}

\author{
Indriyani Ni Made Vita*, Putra I Wayan Gde Yogiswara Darma \\ Faculty of Economics and Business, University of Warmadewa, Indonesia \\ *E-mail: made.vita@yahoo.co.id
}

\begin{abstract}
Covid-19 has had a significant impact on the life of the world community, including in Indonesia. In addition to the health impact, the pandemic also has an economic impact, one of which has an impact on cooperatives. Currently, cooperatives are facing a big challenge in order to run their business properly. The purpose of this study is to understand, describe and analyze the financial performance of the Sahabat Mitra Sejati Savings and Loan Cooperative with digital transformation. The digital transformation carried out by KSP Sahabat Mitra Sejati in the midst of the Covid-19 pandemic has stabilized the cooperative's financial performance. Although during the pandemic, which can be said to have greatly affected the company's business activities, with this digital transformation, KSP Sahabat Mitra Sejati only needs to improve its digital system and innovate so that customers or the people who use it do not have significant problems.
\end{abstract}

\section{KEY WORDS}

Covid-19, digital transformation, financial performance.

The Covid-19 pandemic has had a significant impact on the life of the world community, including in Indonesia. In addition to the health impact, the pandemic also has an economic impact, one of which has an impact on cooperatives. Currently, cooperatives are facing a big challenge in order to run their business properly. The role of cooperatives as a forum for MSMEs and a source of capital is faced with formidable challenges during the Covid-19 pandemic. There is also a big challenge for cooperatives in the midst of the covid-19 pandemic, where many cooperative members withdraw their deposits due to negative issues regarding the insecurity of saving money in cooperatives during the pandemic and the large number of bad loans. Especially after the entry of the industrial revolution 4.0, the Government hopes that cooperative actors can compete on a large scale with digital transformation efforts despite the fact that there are many obstacles faced by business people.

Cooperatives are business entities consisting of people or cooperative legal entities based on their activities based on cooperative principles as well as a people's economic movement based on the principle of kinship. To assess the company's performance from the financial aspect, it can be done through analysis of the financial statements of companies or financial institutions with various analytical tools. The analysis is carried out to obtain information about whether a company has a good level of performance or level of corporate health, which is promising and can maintain its business continuity (Aprilia and Amanah, 2014: 2). Cooperatives as a company require periodic performance appraisals in accordance with their achievements, considering that the success of a cooperative's business will determine the level of soundness of its business (Afandi, 2014:26). Cooperative health assessment is used to determine how healthy the cooperative is in carrying out its business. This performance assessment can be carried out with digitalization efforts in the midst of this Covid-19. In the midst of the digital transformation carried out during this pandemic, it is an opportunity for cooperatives to improve their financial performance. In addition, it can also make cooperatives more productive and innovative. Seeing the economic potential of the digital transformation, efforts to optimize and maximize economic potential need the support of various policies, namely infrastructure, human resources, and regulations. 


\section{LITERATURE REVIEW}

The transformation process contains the dimensions of time and the socio-cultural changes of the people who occupy it that arise through a long process that is always related to the activities that occur at that time. According to Najoan and Johansen (2012), the transformation process goes through 3 stages, namely: Investment, Diffusion, and Consequences. Transformation can happen intentionally and unintentionally. Deliberate transformation is characterized by clear planning, management, and is indicated by the existence of programs and changes that are clearly expected. Deliberate transformation is usually programmed by a community agent to change the ideas, concepts, and culture that exist in society from the less pleasant (good) to the good (favourable). Meanwhile, unintentional transformation is a change that occurs naturally (either due to changes in natural conditions, technology and so on). This change can occur due to influences from within the community itself or from outside the community.

Digitization is the convergence of product and process information applications that can perform various audio-visual and computational functions. The development of modern communication technology that is convergent is a process of convergence of the entire process of mass media evolution (Wuryanta, 2014). Digital theory is always closely related to media, because media continues to develop along with technological advances from old media to new media, making it easier for humans in all fields related to Digital Theory. There are five digital characteristics, namely numerical representation; modularity (the principle of assembling larger units from smaller ones); automation; variability; and transcoding (the relationship between computing and everyday culture) (Manovich (2002) in Aji (2012).

Performance measurement is used by companies to make improvements to their operational activities in order to compete with other companies. Financial performance analysis is a critical assessment process of reviewing data, calculating, measuring, interpreting, and providing solutions to company finances for a certain period. Company performance is a formal effort carried out by the company to evaluate the efficiency and effectiveness of the company's activities that have been carried out in a certain period of time. According to Sucipto (2003) the notion of financial performance is the determination of certain measures that can measure the success of an organization or company in generating profits. Meanwhile, according to IAI (2007) Financial Performance is the company's ability to manage and control its resources.

\section{METHODS OF RESEARCH}

This research is classified as a type of qualitative research because qualitative research is descriptive research and tends to use a deductive approach to analysis. The qualitative approach is expected to be able to produce in-depth descriptions of speech, writing, and or observable behavior of a particular individual, group, community, and organization in a particular context setting which is studied from a complete, comprehensive point of view because every aspect of the object have an indivisible unity. Qualitative research aims to gain a general understanding of social reality from the participant's perspective. This understanding is not determined in advance, but is obtained after analyzing the social reality that is the focus of research (Bachri, 2010). The location in this research is the Sahabat Mitra Sejati Savings and Loan Cooperative which is a cooperative with crossprovincial membership. The object in this study is the digital transformation during the pandemic on the financial performance of the Sahabat Mitra Sejati Savings and Loan Cooperative. This research is based on facts in the field using non-participant observation, structured interviews, and documentation. Non-participant observations were carried out through observing the financial performance of Sahabat Mitra Sejati KSP in digital transformation during the pandemic. Structured interviews (structured interviews), where interviews were conducted using a systematic interview guide and communicated formally. The use of structured interviews is expected to provide comfort to the informants because the informants feel respected to explain the digital transformation in the management of the cooperative that is being carried out. The resource persons in this study were the 
management of KSP Sahabat Mitra Sejati. Documentation is a way to support the results of observations and interviews that have been carried out.

The data analysis technique in this study uses interactive model data analysis as developed by Miles, et. all (2014), namely data condensation, data presentation (data display), and conclusion drawing or verification (conclusion drawing/verification). This study uses an interactive model of data analysis to provide confidence about the validity of the data obtained, so that researchers do not hesitate in drawing conclusions from the research conducted.

\section{RESULTS AND DISCUSSION}

Digital Transformation in the Time of a Pandemic. Cooperative digital transformation is a necessity so cooperatives can be adaptive in this digital economy era. The challenges ahead are getting bigger that require speed, agility and also convenience for members. The Corona pandemic has taught us all how massively we are forced to adapt to new habits. The Covid-19 pandemic has changed the way we work, do activities, learn, and the way we transact, from previously through physical contact (offline) to more online (online). Therefore, this pandemic must be used as a momentum to accelerate digital transformation. Digital transformation is the key to the survival of a business during a pandemic. This can help everyone to work faster and more efficiently, and stay productive in the midst of limited interaction.

According to research respondents, KSP Sahabat Mitra Sejati which is the first Savings and Loan Cooperative to use digitalization, that the use of digital company activities can accelerate business activities. In addition, there is paper less which will also help preserve the environment. However, in its activities using digitization, there are problems that are still being fixed to this day. One of them is that there are several customers, especially the elderly who are still not able to operate digital transactions so that it will affect the company's performance, both in terms of finance and overall. Research respondents in the operational section said that KSP Sahabat Mitra Sejati also cooperates with Bank Sampoerna related to transaction activities between customers and KSP Sahabat Mitra Sejati. This is expected to be able to launch the company's activities, especially in lending and borrowing activities. The first benefit of a savings and loan cooperative is that it can be a source of business capital for its members. When compared to banks, borrowing and applying for business capital is fairly simple and uncomplicated. Savings and loan cooperatives can also provide capital to businesses that are still relatively new or micro. Therefore, savings and loan cooperatives are very helpful for capital, especially for SMEs in Indonesia.

Digital Transformation in Improving Cooperative Financial Performance. Cooperatives began to be introduced to the community with the aim of improving the welfare of the community. The principle of self-help and cooperation has been successfully developed in the management of cooperatives, because these principles are in accordance with the culture that develops in Indonesia. Cooperatives can be classified according to their type, namely based on the similarity of activities regulated in Law No.25/1992 concerning Cooperatives. One type of cooperative in Indonesia is the Savings and Loan Cooperative. KSP Sahabat Mitra Sejati which is a cooperative under the auspices of the government has started its business activities using digitalization. Although initially, Sahabat Mitra Sejati KSP has not fully carried out its activities digitally. However, over time and with the COVID-19 pandemic, KSP Sahabat Mitra Sejati continues to develop digitalization programs to streamline and streamline its activities. As discussed in sub chapter 4.2, research respondents said that there were problems experienced by KSP Sahabat Mitra Sejati in the form of several customers, especially the elderly who were still unable to operate digital transactions so that it would affect the company's performance, both in terms of finances and overall.

According to research respondents, based on the company's performance as seen from the performance of employees, that employees must control their customers more so that they are disciplined in making payments. KSP Sahabat Mitra Sejati employees also have a responsibility to meet the given targets. The employees of KSP Sahabat Mitra Sejati 
become intermediaries to improve the company's performance from a financial perspective, especially from the activity ratio. This is because, if the customer is not disciplined in paying the loan, the receivable/loan turnover ratio will be slower.

Based on the activity ratio of Sahabat Mitra Sejati KSP, that the turn over of receivables or loans of Sahabat Mitra Sejati KSP in 2019 of 0.15 times can still be maintained in 2020 with the same amount of 0.15 times even during this covid-19 pandemic. . When viewed from loan turnover, loan turnover is still below number 1 . This receivable/loan turnover is still fairly slow. Research respondents said that this is getting better with digital transformation. Research respondents also said that the digitization used by KSP Sahabat Mitra Sejati was very helpful during the Covid-19 pandemic, in addition to controlling transactions, the company's financial performance could still be stable even though in the field there were still some customers who were still difficult to make loan payments due to the existence of other factors such as layoffs. However, this does not affect the financial performance of Sahabat Mitra Sejati KSP. Likewise, the liquidity ratio is still above 1, which means that the company is safe to pay its obligations. Meanwhile, the solvency ratio is less than 1 , which means that the financial condition of Sahabat Mitra Sejati KSP with respect to its obligations is still considered good.

Cooperative financial performance is a benchmark for cooperative health amid the Covid-19 pandemic. Research respondents said that in the midst of the growing Covid-19 pandemic, KSP Sahabat Mitra Sejati will continue to make improvements to the digital system so that later people will not have significant problems using the Sahabat Mitra Sejati KSP system. This is also done to maintain the financial performance of the cooperative. However, the management remains optimistic that the financial performance of Sahabat Mitra Sejati KSP can be better than today. The strategy is to provide the best possible service both online and in person. Research respondents added that in addition to providing ease of transaction, speed and accuracy in service, the management also provides security guarantees for customers. So that customers don't have to worry about the funds they save at KSP Sahabat Mitra Sejati.

\section{CONCLUSION}

Based on the discussion, it was concluded that the financial performance of cooperatives is a benchmark for cooperative health amid the Covid-19 pandemic. KSP Sahabat Mitra Sejati which is a cooperative under the auspices of the government, has carried out its activities using a digitalization system. The digital transformation carried out by KSP Sahabat Mitra Sejati in the midst of the Covid-19 pandemic has stabilized the cooperative's financial performance. Although during the pandemic, which can be said to have greatly affected the company's business activities, with this digital transformation, KSP Sahabat Mitra Sejati only needs to improve its digital system and innovate so that customers or the people who use it do not have significant problems. KSP Sahabat Mitra Sejati which has stable financial performance during this pandemic also has employees who are actively reaching their targets, so that their customers remain disciplined in paying loans. Where this will help speed up the turnover of receivables or loans from KSP Sahabat Mitra Sejati.

Based on the conclusion, the suggestion that the author can give is that further research should be carried out on the impact of the digital transformation of cooperatives when the Covid-19 pandemic has ended. This is expected to be able to compare the effectiveness and efficiency of cooperatives during and after the pandemic.

\section{REFERENCES}

1. Afandi, P. 2014. Financial Performance Analysis to Measure Financial Health of KSU BMT Arafah Cooperative Bancak District, Semarang Regency. Journal of Among Makati, Vol 7 (13).

2. Aprilia and Amanah. 2014. Analysis of Financial Ratios to Measure Financial Performance in the Dhaya Harta Jombang Cooperative. Journal of Accounting Science and Research, Vol 3 (4). 
3. Bachri, B. S. 2010. Convincing Data Validity through Triangulation in Qualitative Research. Journal of Educational Technology. 10(1): 46-62.

4. Miles, M.B., Huberman, A.M and Saldana, J. 2014. Qualitative data analysis: A Methods sourcebook 3rd, Thousand Oaks, CA: Sage.

5. Najoan, S, J. and Johansen M. 2011. Transformation as a Design Strategy. Matrasain Media, 8(2):117-130.

6. Sucipto.2003. Financial Performance Assessment. Article FE University of North Sumatra.

7. Wuryanta, W. E. 2014. Digitalization of Society: Looking at the Strengths and Weaknesses of the Dynamics of the Digital Information Age and the Information Society. Journal of Communication Studies, 1(2):131-142. 